\title{
Effect of Herbicides and Handweeding on Establishment of Kleingrass and Buffelgrass
}

\author{
B.W. BOVEY, R.E. MEYER, M.G. MERKLE, AND E.C. BASHAW
}

\section{Abstract}

In the greenhouse, kleingrass [Panicum coloratum (L.) 'Selection 75'] and buffelgrass [Cenchrus ciliaris (L.) 'Nueces'] were tolerant of preemergence application of butylate ( $S$-ethyl bis(2methylpropyl)carbamothioate) and early postemergence sprays of barban (4-chloro-2-butynyl 3-chlorophenylcarbamate) and siduron [ $N$-(2-methylcyclohexyl)- $N^{\prime}$-phenylurea]. Kleingrass tolerated early postemergence sprays of bromoxynil (3,5-dibromo-4-hydroxybenzonitrile), but bromoxynil injured buffelgrass. In the field, the most promising treatments for kleingrass establishment, compared with handweeding, included postemergence sprays of 2,4-D [(2,4dichlorophenoxy) acetic acid $\mathbf{b}$ preemergence application of siduron, and ropewick application of glyphosate [N-(phosphonomethy)glycine]. Once established, kleingrass seedlings tolerate extreme drought during the growing season where weeds had been controlled.

Kleingrass (Panicum coloratum) and buffelgrass (Cenchrus ciliaris) are warm-season, perennial grasses native to South Africa that are highly important for livestock use on Texas rangelands (Holt and Bashaw 1976). These grasses, however, are sometimes difficult to establish in the field because of poor seedling vigor and severe competition from weeds. Few data are available on the use of herbicides for weed control in newly planted areas of kleingrass or buffelgrass.

Previous investigations (Bovey et al. 1979) showed that greenhouse-grown kleingrass tolerated preemergence and early postemergence sprays of propazine (See Table 1 for chemical names) at $1.1 \mathrm{~kg} / \mathrm{ha}$, but did not tolerate picloram, 2,4-D, dicamba, hexazinone, or tebuthiuron at similar rates. In another greenhouse study (Bovey et al. 1980), propazine was the only herbicide of 9 investigated that showed promise for both pre- and post emergence applications in kleingrass and buffelgrass. Buffelgrass tolerated preemergence sprays of clopyralid but 2,4-D, dicamba, 2,4,5-T, triclopyr, hexazinone, and tebuthiuron were phytotoxic (Bovey et al. 1983). When 45 days old, buffelgrass tolerated postemergence applications of 2,4-D, dicamba, clopyralid, and picloram at 2.2 $\mathrm{kg} / \mathrm{ha}$, but top growth production was reduced by most rates of tebuthiuron and hexazinone.

In these experiments, we determined the tolerance of greenhousegrown kleingrass and buffelgrass seedlings to several preemergence or postemergence herbicides as listed in Table 1. Herbicides were selected based on excellent weed control potential but their phytotoxicity to kleingrass and buffelgrass was usually unknown. Similar treatments also were evaluated in the field to determine their potential for weed control and for kleingrass establishment.

\section{Materials and Methods}

\section{Greenhouse Experiments}

Kleingrass 'Selection 75' and buffelgrass 'Nueces' seedlings were grown in the greenhouse in pots $9.5 \mathrm{~cm}$ in diam and $7 \mathrm{~cm}$ deep containing a 1:1:1 Bleiberville clay (Udic Pellustert): sand: peat moss mixture. Twenty-five seeds of each grass were placed uniformly in each plot and covered with $5 \mathrm{~mm}$ of sand. Five replica-

\footnotetext{
Authors Bovey, Mcycr, and Bashaw are research agronomist, plant physiologist, and geneticist, USDA-ARS, Dep. Range Sci., Dep. Range Sci., and Dep. Soil and Crop Sci., Texas A\&M Univ., College Station 77843; Merkle is professor, Dep. Soil and Crop Science, Texas A\&M Univ., College Station 77843.

Cooperative investigation of USDA, Agr. Res. Serv. and the Texas Agr. Exp. Sta., Texas A\&M Univ. This paper reports the results of research only. Mention of a pesticide in his paper does not constitute a recommendation by the USDA nor does it imply registration under FIFRA.

Manuscript accepted 2 April 1986.
}

Table 1. Common names, chemical names, and type of activity of herbicides used in this study.

\begin{tabular}{cc}
\hline \hline $\begin{array}{c}\text { Common } \\
\text { name }\end{array}$ & $\begin{array}{r}\text { Type of } \\
\text { activity }\end{array}$ \\
\hline
\end{tabular}

Acifluorfen 5-[2-chloro-4-(trifluoromethyl)phenoxy]2-nitrobenzoic acid

pre, poe

Asulam methyl[-4-aminophenyl)sulfonyl]carbamate poe

Barban 4-chloro-2-butynyl 3-chlorophenylcar-

bamate

Bifenox methyl 5-(2,4-dichlorophenoxy)-2-nitrobenzoate

Bromoxynil 3,5-dibromo-4-hydroxybenzonitrile

Butylate $S$-ethyl bis(2-methylpropyl)carbamothioate

Butylate + butylate + (2,2-dichloro- N,N-di-2-propenyl-

dichlormid acetamide) (24:1 mixture)

Clopyralid 3,6-dichloro-2-pyridinecarboxylic acid

Cyanazine 2-([4-chloro-6-(ethylamino)-1,3,5-triazin2-yl]amino)-2-methylpropanenitrile

Dalapon 2,2-dichloropropanoic acid

Dicamba 3,6-dichloro-2-methoxybenzoic acid

Diclofop (士)-2-[4-(2,4-dichlorophenoxy)phenoxy] propanoic acid

\section{2,4-D (2,4-dichlorophenoxy)acetic acid}

Diethatyl $\quad N$-(chloroacetyl)- $N$-(2,6-diethylphenyl) glycine

EPTC $S$-ethyl dipropyl carbamothioate

EPTC + EPTC + (2,2-dichloro- $N, N$-di-2-propeny-

dichlormid lacetamide) (12:1 mixture)

Ethofumesate $( \pm)$-2-ethoxy-2,3-dihydro-3,3-dimethyl-5benzofuranyl methanesulfonate

Glyphosate $N$-(phosphonomethyl)glycine

Hexazinone 3-cyclohexyl-6-(dimethylamino)-1-methyl1,3,5-triazine-2,4(1H,3H)-dione

poe

Metribuzin 4-amino-6-(1,1-dimethylethyl)-3(methylthio)-1,2,4-triazin-5(4H)-one

Oryzalin 4-(dipropylamino)-3,5-dinitrobenzenesulfonamide

pre, poe

poe

ppi, pre

ppi, pre

poe

pre, poe

poe

poe

pre, poe

poe

pre

ppi

ppi

pre

poe

pre, poe

pre, poe

pre

3-[2,4-dichloro-5-(1-methylethoxy)phenyl]5-(1,1-dimethylethyl)1-3,4-oxadiazol2-(3H)-one

Oxyfluorfen 2-chloro-1-(3-ethoxy-4-nitrophenoxy)-4 (trifluoromethyl)benzene

Picloram 4-amino-3,5,6-trichloro-2-pyridinecarboxylic acid

Profluralin $N$-(cyclopropylmethyl)-2,6-dinitro- $N$ -

propyl-4-(trifluoromethyl)benzenamine ppi

Propazine 6-chloro- $N, N^{\prime}$-bis(1-methylethyl) 1-3,5triazine-2,4-diamine

Pyrazon 5-amino-4-chloro-2-phenyl-3(2H)-pyridazinone

Siduron

$N$-(2-methylcyclohexyl)- $N^{\prime \prime}$-phenylurea

2,4,5-T (2,4,5-trichlorophenoxy)acetic acid

Tebuthiuron $N-[5-(1,1-$ dimethylethyl)-1,3,4-thiadiazol2-yl]- $N, N$-dimethylurea

Terbutryn N-(1,1-dimethylethyl)-N'ethyl-6-(methyIthio)-1,3,5-triazine-2,4-diamine

pre

pre, poe

poe

pre

pre, poe

pre

poe

pre, poe

Triclopyr

[(3,5,6-trichloro-2-pyridinyl)oxy]acetic acid pre poe

Trifluralin 2,6-dinitro- $N, N$-dipropyl-4-(trifluoromethyl)benzenamine

pre

Vernolate S-propyl dipropylcarbamothioate ppi

'Source: Weed Science Terminology. 1985. Weed Sci. Soc. Am. Supple. 1, 33:1-23. pre $=$ preemergence; $\mathbf{p p i}=$ preplant incorporated $;$ poe = postemergence. 
tions (pots) were used for each treatment. Unless otherwise indicated, herbicides were applied either preemergence one day after planting or postemergence 10 to 14 days after emergence when seedlings were in the 2-leaf stage and were 2 to $6 \mathrm{~cm}$ tall.

Herbicides (Tables 1, 2, 3, and 4) were applied in water at a volume of $93.5 \mathrm{~L} / \mathrm{ha}$ at rates of $0.6,1.1$, and $2.2 \mathrm{~kg} / \mathrm{ha}$ in a laboratory sprayer (Bouse and Bovey 1967). The pots were returned to the greenhouse and hand-watered after 24 hours with a sprinkler and daily thereafter. Mean night and day greenhouse temperatures were 28 and $35^{\circ} \mathrm{C}$, respectively, from June to October 1980.

Since kleingrass and buffelgrass showed considerable tolerance to butylate and siduron when applied preemergence, we incorporated these herbicides at $0.6,1.1,2.2$ and $4.5 \mathrm{~kg} /$ ha into the soil by watering immediately after treatment (Table 4). In previous experiments, butylate was neither incorporated into the soil nor watered into the soil until 24 hours after application. Because butylate will vaporize from the surface of moist soil, it was desirable to investigate the effect of soil incorporation of butylate. In these experiments the commercial preparation of butylate + dichlormid (24:1), a safener for corn (Zea mays) was included.

Postemergence herbicides were evaluated by visually estimating either percent desiccation, percent dead plants, or both per pot. Plants showing complete desiccation were considered dead. Injury from preemergence herbicides was evaluated by visually estimating the percent of plants failing to emerge (percent dead plants) compared with the controls of percent desiccation of emerged plants, if any. Evaluations were made 14 days after treatment. All experiments were conducted twice in a completely randomized design, and data were pooled for presentation. Data were subjected to
Table 4. Desiceation (injury) of kleingrass and buffelgrass 14 days after treatment with butylate + dichlormid (24:1) and siduron applied preemergence and watered immediately after planting in the greenhouse.

\begin{tabular}{|c|c|c|c|}
\hline Herbicide & Rate & Kleingrass & Buffelgrass \\
\hline & (kg/ha) & -1 & 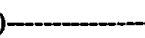 \\
\hline \multirow{4}{*}{$\begin{array}{r}\text { Butylate + dichlormid } \\
\qquad(24: 1)\end{array}$} & 0.6 & $19 \mathrm{de}$ & $0 \mathrm{~d}$ \\
\hline & 1.1 & $14 \mathrm{e}$ & $10 \mathrm{~cd}$ \\
\hline & 2.2 & $17 \mathrm{e}$ & $13 \mathrm{~b}-\mathrm{d}$ \\
\hline & 4.5 & $27 \mathrm{c}$ & $39 a-d$ \\
\hline \multirow[t]{4}{*}{ Siduron } & 0.6 & $31 \mathrm{c}$ & 29 a-d \\
\hline & 1.1 & $25 \mathrm{~cd}$ & 54 a-c \\
\hline & 2.2 & $40 \mathrm{~b}$ & $50 \mathrm{ab}$ \\
\hline & 4.5 & $75 \mathrm{a}$ & $68 a$ \\
\hline Untreated & - & $15 \mathrm{e}$ & $9 \mathrm{~cd}$ \\
\hline
\end{tabular}

IValues in columns followed by the same letter do not differ significantly at the $5 \%$ level according to Duncn's multiple range test.

analysis of variance and means were compared using Duncan's multiple range test (Steel and Torrie 1980).

\section{Field Experiments}

Treatments were made at 2 locations in Texas in 1980 and 1981. The College Station and Wellborn site consisted of Lufkin fine sandy loam, a member of the fine montmorillonitic, thermic Vertic Albaqualfs. The predominant weed at College Station was broadleaf signalgrass (Brachiaria platyphylla). Other species included southern crabgrass (Digitaria ciliaris), junglerice (Echinochloa colonum), Texas panicum (Panicum texanum), common purslane

Table 2. Desiccation (injury) of kleingrass and buffelgrass 14 days after treatment with preemergence herbicides in the greenhouse.

\begin{tabular}{|c|c|c|c|c|c|c|}
\hline \multirow[b]{3}{*}{ Herbicide } & \multicolumn{6}{|c|}{ Rate, $\mathrm{kg} / \mathrm{ha}^{2}$} \\
\hline & \multicolumn{2}{|c|}{0.6} & \multicolumn{2}{|c|}{1.1} & \multicolumn{2}{|c|}{2.2} \\
\hline & Kleingrass & Buffelgrass & Kleingrass & Buffelgrass & Kleingrass & Buffelgrass \\
\hline $\begin{array}{l}\text { Butylate } \\
\text { Pyrazon } \\
\text { Profluralin } \\
\text { Trifluralin } \\
\text { Diclofop } \\
\text { Bifenox } \\
\text { Oryzalin } \\
\text { Oxyfluorfen } \\
\text { Untreated }\end{array}$ & $\begin{array}{c}6 \mathrm{i} \\
11 \mathrm{hi} \\
19 \mathrm{~g}-\mathrm{i} \\
41 \mathrm{e}-\mathrm{g} \\
69 \mathrm{~b}-\mathrm{d} \\
81 \mathrm{a}-\mathrm{c} \\
94 \mathrm{ab} \\
100 \mathrm{a} \\
10 \mathrm{hi}\end{array}$ & $\begin{array}{c}6 \mathrm{~h} \\
38 \mathrm{e}-\mathrm{g} \\
91 \mathrm{ab} \\
86 \mathrm{a}-\mathrm{c} \\
95 \mathrm{ab} \\
62 \mathrm{c}-\mathrm{e} \\
69 \mathrm{~b}-\mathrm{d} \\
100 \mathrm{a} \\
8 \mathrm{~h}\end{array}$ & $\begin{array}{c}4 \mathrm{i} \\
35 \mathrm{f}-\mathrm{h} \\
53 \mathrm{~d}-\mathrm{f} \\
50 \mathrm{~d}-\mathrm{f} \\
84 \mathrm{a}-\mathrm{c} \\
92 \mathrm{a}-\mathrm{c} \\
98 \mathrm{ab} \\
100 \mathrm{a} \\
10 \mathrm{hi}\end{array}$ & $\begin{array}{c}9 \mathrm{~h} \\
50 \mathrm{~d}-\mathrm{f} \\
96 \mathrm{ab} \\
95 \mathrm{ab} \\
96 \mathrm{ab} \\
87 \mathrm{a}-\mathrm{c} \\
81 \mathrm{a}-\mathrm{c} \\
100 \mathrm{a} \\
8 \mathrm{~h}\end{array}$ & $\begin{array}{c}3 \mathrm{i} \\
96 \mathrm{ab} \\
94 \mathrm{ab} \\
88 \mathrm{a}-\mathrm{c} \\
96 \mathrm{ab} \\
99 \mathrm{ab} \\
98 \mathrm{ab} \\
100 \mathrm{a} \\
10 \mathrm{hi}\end{array}$ & $\begin{array}{c}8 \mathrm{~h} \\
94 \mathrm{ab} \\
100 \mathrm{a} \\
99 \mathrm{a} \\
99 \mathrm{a} \\
100 \mathrm{a} \\
97 \mathrm{a} \\
100 \mathrm{a} \\
8 \mathrm{~h}\end{array}$ \\
\hline
\end{tabular}

${ }_{1}$ Acifluorfen, cyanazine, diethatyl, ethofumesate, metribuzin, and oxadiazon, terbutryn, were highly phytotoxic to kleingrass and buffelgrass ( 94 to $100 \%$ desiccation) at $0.6,1.1$, and 2.2. $\mathrm{kg} / \mathrm{ha}$.

2Values within all columns for each grass species followed by the same letter do not differ significanlty at the 5\% level according to Duncan's multiple range test.

Table 3. Desiccation (injury) of kleingrass and buffelgrass 14 days after treatment with postemergence herbicides in the greenhouse.1

\begin{tabular}{|c|c|c|c|c|c|c|}
\hline \multirow[b]{3}{*}{ Herbicide } & \multicolumn{6}{|c|}{ Rate, kg/ha ${ }^{2}$} \\
\hline & \multicolumn{2}{|c|}{0.6} & \multicolumn{2}{|c|}{1.1} & \multicolumn{2}{|c|}{2.2} \\
\hline & Kleingrass & Buffelgrass & Kleingrass & Buffelgrass & Kleingrass & Buffelgrass \\
\hline Bromoxynil & $17 \mathrm{i}-\mathbf{n}$ & $43 j-0$ & $22 h-n$ & $43 j-0$ & $29 \mathrm{i}-\mathrm{j}$ & $69 \mathrm{e}-\mathrm{j}$ \\
\hline Barban & $12 \mathrm{mn}$ & $20 n-q$ & $14 k-n$ & $221-q$ & $18 i-n$ & $160-q$ \\
\hline Pyrazon & $12 \mathrm{mn}$ & $11 \mathrm{q}$ & $17 i-n$ & $160-q$ & $60 \mathrm{de}$ & 90 a-d \\
\hline Asulam & $18 \mathrm{i}-\mathrm{n}$ & $72 \mathrm{~b}-\mathrm{i}$ & $24 \mathrm{k}-\mathrm{m}$ & $77 a-f$ & $27 \mathrm{~h}-1$ & 78 a-f \\
\hline Diclofop & $41 \mathrm{fg}$ & $97 a-c$ & $80 \mathrm{bc}$ & $99 \mathrm{a}$ & $90 \mathrm{ab}$ & $100 \mathrm{a}$ \\
\hline Bifenox & $14 k-n$ & $13 \mathrm{q}$ & $21 \mathrm{i}-\mathrm{n}$ & $30 \mathrm{~m}-\mathrm{q}$ & $30 \mathrm{~g}-\mathrm{i}$ & $45 \mathrm{i}-\mathrm{n}$ \\
\hline Cyanazine & $96 a$ & $88 a-d$ & $100 \mathrm{a}$ & $100 \mathrm{a}$ & $100 \mathrm{a}$ & $100 a$ \\
\hline Untreated & $10 n$ & $14 q$ & $10 n$ & $14 \mathrm{q}$ & $10 \mathrm{n}$ & $14 \mathrm{q}$ \\
\hline
\end{tabular}

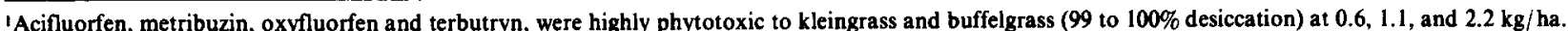

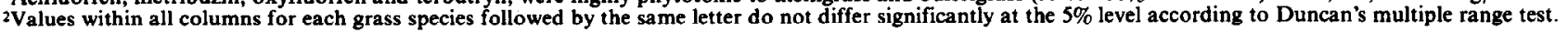


(Portulace oleracea), horse purslane (Trianthema portulacastrum), redroot pigweed (Amaranthus retroflexus), carpetweed (Mollugo verticillata), yellow nutsedge (Cyperus esculentus), and prostrate spurge (Euphorbia supina). At Wellborn the primary weedy species were woolly croton (Croton capitatus) and yellow nutsedge, with scattered plants of western ragweed (Ambrosia psilostachya), Johnsongrass (Sorghum halepense), bermudagrass (Cynodon dactylon), brownseed paspalum (Paspalum plicatulum), and roundseed dichanthelium (Dichanthelium sphaerocarpon). Herbicide, handweeded, or mowing treatments were applied to 3 by $6-\mathrm{m}$ plots in triplicate. Kleingrass 'Selection 75 ' was seeded with a modified row-crop planter calibrated to deliver $2.5 \mathrm{~kg} /$ ha pure live seed in 6 rows spaced $0.5 \mathrm{~m}$ apart in each plot. All herbicides were applied in water with a hand carried boom at a spray volume of $187 \mathrm{~L} /$ ha at a pressure of $207 \mathrm{kPa}$. In 1980, vernolate, EPTC, EPTC + dichlormid and butylate were applied preplant incorporated (ppi) on 5 May; propazine, pyrazon, and siduron were applied preemergence (pre) on 13 May; and bromoxynil, asulam, 2,4-D, and glyphosate were applied postemergence (poe) on 11 June at both locations. Preplant incorporated treatment consisted of hand raking the herbicide into the soil to a depth of $2.5 \mathrm{~cm}$. A handweeded, weedfree treatment was also included. In 1981, preplant, preemergence, and postemergence herbicides were applied 21 and 24 April, and 11 May, respectively. Kleingrass was planted on 21 April. The same herbicide treatments were applied in 1981 as in 1980 with the addition of preemergence sprays of dalapon and glyphosate, 4 ropewick treatments with glyphosate, and mowing. Ropewick treatments consisting of a 1.1 mixture of glyphosate and water were made on 11, 20, and 27, May and 8 June 1981. Mowed plots left an 8-cm stubble. Plots of one treatment were mowed 28 May and $14 \mathrm{July}$, and in another, only $14 \mathrm{July}$. A handweeded, as needed, weed-free treatment was included at both sites in both years. Herbicides and rates used are presented in the tables.

Density of kleingrass and major weeds was recorded approximately 1 month after treatment by counting each species in 5 randomly selected 25 by $25-\mathrm{cm}$ areas in each plot. Kleingrass and weed counts were converted to plants per $\mathrm{m}^{2}$ for each plot. Percent ground cover for each species was also visually estimated after 6 months in each treated area. Data were analyzed as a randomized complete block design with means compared using the Fisher Least Significant Difference Test (LSD) at the 5\% level (Steel and Torrie 1980).

\section{Results and Discussions}

\section{Greenhouse Experiments}

Butylate applied preemergence did not reduce germination or seedling growth of kleingrass at rates up to and including $2.2 \mathrm{~kg} / \mathrm{ha}$ (Table 2). Kleingrass was tolerant to pyrazon and profluralin at 0.6 $\mathrm{kg} / \mathrm{ha}$ but was killed at $2.2 \mathrm{~kg} / \mathrm{ha}$. Acifluorfen, bifenox, cyanazine, diclofop, diethatyl, ethofumesate, metribuzin, oryzalin, oxadiazon, oxyfluorfen, terbutryn, and trifluralin were highly injurious regardless of rate, usually killing most or all plants. As with kleingrass, butylate was the only herbicide that did not injure buffelgrass. All other herbicides, at all rates, severely injured buffelgrass.

Of the postemergence treatments, kleingrass and buffelgrass tolerated barban at all rates (Table 3). Kleingrass also tolerated bromoxynil, pyrazon, and bifenox at 0.6 and $1.1 \mathrm{~kg} / \mathrm{ha}$. Acifluorfen, cyanazine, metribuzin, oxyfluorfen, and terbutryn were extremely phytotoxic to seedling kleingrass and buffelgrass even at the lowest application rate. Buffelgrass tolerated bifenox and pyrazon at 0.6 and $1.1 \mathrm{~kg} / \mathrm{ha}$ but was injured by asulam, bromoxynil, and diclofop at these rates.

When applied preemergence and watered into the soil immediately after treatment, butylate + dichlormid did not injure either kleingrass at rates below $4.5 \mathrm{~kg} / \mathrm{ha}$ or buffelgrass at $4.5 \mathrm{~kg} / \mathrm{ha}$ or less (Table 4). Siduron applied preemergence usually injured both kleingrass and buffelgrass (Table 4). As rates of siduron increased, injury to the grasses generally increased. Siduron applied poste- mergence at rates of $2.2 \mathrm{~kg} /$ ha did not injure 14-day-old seedlings of either kleingrass or buffelgrass (data not shown).

\section{Field Experiments-Kleingrass Tolerance}

In 1980 propazine at $2.2 \mathrm{~kg} /$ ha and pyrazon and siduron at 2.2 and $4.5 \mathrm{~kg} /$ ha significantly $(P>0.05)$ reduced kleingrass numbers compared to the untreated areas at Wellborn (Table 5). At College Station, vernolate at $2.2 \mathrm{~kg} / \mathrm{ha}$ and pyrazon at $4.5 \mathrm{~kg} / \mathrm{ha}$ and siduron at 2.2 and $4.5 \mathrm{~kg} /$ ha reduced kleingrass stands. When butylate + dichlormid (hereafter called butylate) + propazine were combined at $2.2+2.2 \mathrm{~kg} / \mathrm{ha}$, kleingrass numbers were reduced compared to the untreated areas at College Station. No other preplant incorporated or preemergence herbicides reduced kleingrass stands compared to the untreated areas. At both locations the

Table 5. Effect of herbicides, mowing, and handweeding on kleingrass populations 1 month after treatment at Wellborn and College Station, TX.1

\begin{tabular}{|c|c|c|c|c|c|}
\hline \multirow[b]{3}{*}{$\begin{array}{l}\text { Herbicide or } \\
\text { treatment }\end{array}$} & \multirow[b]{3}{*}{ Rate } & \multicolumn{4}{|c|}{ Year and location } \\
\hline & & \multicolumn{2}{|c|}{1980} & \multicolumn{2}{|c|}{1981} \\
\hline & & Wellborn & $\begin{array}{l}\text { College } \\
\text { Station }\end{array}$ & Wellborn & $\begin{array}{l}\text { College } \\
\text { Station }\end{array}$ \\
\hline \multicolumn{2}{|c|}{ Preplant incorporated (kg/ha) } & \multicolumn{4}{|c|}{ (Plants $\left./ \mathrm{m}^{2}\right)$} \\
\hline EPTC + dichlormid & $\begin{array}{l}2.2 \\
4.5\end{array}$ & $\begin{array}{r}129 \\
77\end{array}$ & $\begin{array}{r}147 \\
81\end{array}$ & $\begin{array}{r}142 \\
23\end{array}$ & $\begin{array}{l}17 \\
20\end{array}$ \\
\hline EPTC & $\begin{array}{l}2.2 \\
4.5\end{array}$ & $\begin{array}{r}88 \\
130\end{array}$ & $\begin{array}{r}83 \\
165\end{array}$ & $\begin{array}{l}64 \\
44\end{array}$ & $\begin{array}{l}9 \\
8\end{array}$ \\
\hline Vernolate & $\begin{array}{l}2.2 \\
4.5\end{array}$ & $\begin{array}{r}135 \\
89\end{array}$ & $\begin{array}{l}71 \\
87\end{array}$ & $\begin{array}{r}90 \\
7\end{array}$ & $\begin{array}{l}7 \\
0\end{array}$ \\
\hline $\begin{array}{l}\text { Butylate }+ \\
\text { dichlormid }\end{array}$ & $\begin{array}{l}2.2 \\
4.5\end{array}$ & $\begin{array}{l}139 \\
100\end{array}$ & $\begin{array}{l}184 \\
134\end{array}$ & $\begin{array}{l}41 \\
36\end{array}$ & $\begin{array}{l}56 \\
13\end{array}$ \\
\hline \multicolumn{6}{|l|}{ Preemergence } \\
\hline Propazine & $\begin{array}{l}1.1 \\
2.2\end{array}$ & $\begin{array}{l}57 \\
14\end{array}$ & $\begin{array}{l}154 \\
108\end{array}$ & $\begin{array}{r}21 \\
0\end{array}$ & $\begin{array}{l}0 \\
0\end{array}$ \\
\hline Pyrazon & $\begin{array}{l}2.2 \\
4.5\end{array}$ & $\begin{array}{l}7 \\
3\end{array}$ & $\begin{array}{r}109 \\
23\end{array}$ & $\begin{array}{r}67 \\
0\end{array}$ & $\begin{array}{r}13 \\
0\end{array}$ \\
\hline Siduron & $\begin{array}{l}2.2 \\
4.5\end{array}$ & $\begin{array}{l}7 \\
0\end{array}$ & $\begin{array}{l}46 \\
46\end{array}$ & $\begin{array}{r}29 \\
4\end{array}$ & $\begin{array}{r}17 \\
3\end{array}$ \\
\hline $\begin{array}{l}\text { Butylate + } \\
\text { Propazine }\end{array}$ & $1.1+1.1$ & 48 & 84 & 3 & 0 \\
\hline Handweeded & $2.2+2.2$ & $\begin{array}{r}42 \\
176\end{array}$ & $\begin{array}{r}61 \\
178\end{array}$ & $\begin{array}{r}0 \\
194\end{array}$ & $\begin{array}{r}0 \\
128\end{array}$ \\
\hline Untreated & & 120 & 164 & 52 & 43 \\
\hline $\begin{array}{l}\text { LSD 5\% for ppi \& } \\
\text { pre herbicides }\end{array}$ & & 84 & 85 & 86 & 53 \\
\hline \multicolumn{6}{|l|}{ Postemergence } \\
\hline $\begin{array}{l}\text { Asulam } \\
2,4-\mathrm{D}\end{array}$ & $\begin{array}{l}2.2 \\
1.1\end{array}$ & $\begin{array}{l}13 \\
58\end{array}$ & $\begin{array}{l}87 \\
78\end{array}$ & $\begin{array}{r}1 \\
61\end{array}$ & $\begin{array}{l}1 \\
4\end{array}$ \\
\hline Bromoxynil & 1.1 & 33 & 37 & 21 & 37 \\
\hline Dalapon & 4.5 & - & - & 6 & 9 \\
\hline Glyphosate & 1.1 & - & - & 33 & 2 \\
\hline $\begin{array}{l}\text { Ropewick Applicatio } \\
\text { (1:1 water: } \\
\text { Glyphosate) } \\
(5 / 11 / 81)\end{array}$ & on on & - & - & 89 & 8 \\
\hline
\end{tabular}

Ropewick Application on

(1:1 water:

Glyphosate)

(5/11/81)

$(5 / 20 / 81)$

$(5 / 27 / 81)$

$(6 / 17 / 81)$

Mowed once

$(5 / 28 / 81)$

Mowed twice

(5/28 and $7 / 14 / 81)$

Handweeded

Untreated

LSD 5\% for poe herbicides

-

$\begin{array}{rrrr}- & - & 83 & 21 \\ \overline{72} & \overline{70} & 109 & 85 \\ - & - & 90 & 16 \\ & & & 24 \\ \overline{99} & - & 67 & 44 \\ 50 & 119 & 134 & 63 \\ 55 & 101 & 46 & 37 \\ \end{array}$

'Areas were seeded 9 May 1980 and 21 April 1981 at Wellborn and College Station, TX respectively. Preplant incorporated, preemergence, and postemergence herbicides were applied on 5 May, 13 May, and 11 June 1980 and 21 April, 24 April, and 11 May 1981, respectively. Handweeded as needed. 
handweeded areas tended to have the highest kleingrass stands $\left(176-178\right.$ plants $/ \mathrm{m}^{2}$ ) but they were not always significantly $(P>$ 0.05 ) higher than some of the herbicide treatments (Table 5).

In 1980, none of the herbicides applied postemergence significantly $(P>0.05)$ reduced kleingrass numbers compared to the untreated plots (Table 5). Kleingrass numbers in the handweeded areas at Wellborn were higher $\left(99\right.$ plants $\left./ \mathrm{m}^{2}\right)$ than when treated with asulam $\left(13\right.$ plants $\left./ \mathrm{m}^{2}\right)$ or bromoxynil $\left(33\right.$ plants $\left./ \mathrm{m}^{2}\right)$.

In 1981, highest kleingrass numbers in areas treated with preplant incorporated and preemergence herbicides occurred at both locations in the handweeded areas except for EPTC + dichlormid applied at $2.2 \mathrm{~kg} / \mathrm{ha}$ at Wellborn (Table 5). Plots treated with all other preplant incorporated or preemergence herbicides were no different from the untreated plots. Postemergence applications of asulam, bromoxynil, dalapon, and glyphosate significantly reduced kleingrass populations at Wellborn compared to populations in the handweeded area (Table 5). At College Station, kleingrass survival was reduced by postemergence sprays of asulam, 2,4-D, dalapon, and glyphosate and ropewick application with glyphosate on 11 May 1981 when compared with kleingrass population in the handweed treatment. But no treatment reduced kleingrass at either site when compared with that in the untreated plots.

In 1980, 6 months after treatment at Wellborn, most successful establishment of kleingrass occurred when treated with 2,4-D (45\% ground cover) or in areas handweeded ( $68 \%$ ground cover) (Table 6). Only selected treatments as listed in Table 5 are shown in Table

Table 6. Effect of herbicides, mowing, and handweeding on percent ground cover of kleingrass 6 months after seeding on 9 May 1980 and 21 April 1981 at Wellborn and College Station, TX.

\begin{tabular}{|c|c|c|c|c|c|}
\hline \multirow[b]{3}{*}{$\begin{array}{l}\text { Herbicide or } \\
\text { treatment }\end{array}$} & \multirow[b]{3}{*}{ Rate } & \multicolumn{4}{|c|}{ Year and location } \\
\hline & & \multicolumn{2}{|c|}{1980} & \multicolumn{2}{|c|}{1981} \\
\hline & & Wellborn & $\begin{array}{l}\text { College } \\
\text { Station }\end{array}$ & Wellborn & $\begin{array}{l}\text { College } \\
\text { Station }\end{array}$ \\
\hline Preemergence & (kg/ha) & \multicolumn{4}{|c|}{$-(\%$ ground cover $)$} \\
\hline Siduron & $\begin{array}{l}2.2 \\
4.5\end{array}$ & $\begin{array}{l}4 \\
5\end{array}$ & $\begin{array}{l}7 \\
3\end{array}$ & $\begin{array}{l}7 \\
7\end{array}$ & $\begin{array}{l}37 \\
27\end{array}$ \\
\hline $\begin{array}{l}\text { Postemergence } \\
\text { 2,4-D }\end{array}$ & 1.1 & 45 & 5 & 30 & 3 \\
\hline \multicolumn{6}{|c|}{$\begin{array}{l}\text { Ropewick Application on } \\
\text { (1:1 water: } \\
\text { glyphosate) }\end{array}$} \\
\hline$(5 / 11 / 81)$ & - & - & - & 37 & 18 \\
\hline$(5 / 20 / 81$ & - & - & - & 42 & 2 \\
\hline$(5 / 27 / 81)$ & - & 一 & - & 27 & 18 \\
\hline$(6 / 17 / 81)$ & - & 14 & 21 & 18 & 8 \\
\hline Mowed once & & & & & \\
\hline $\begin{array}{c}(5 / 28 / 81) \\
\text { Mowed twice }\end{array}$ & - & 一 & - & 33 & 22 \\
\hline$(5 / 28$ and $7 / 14 / 81)$ & - & - & - & 38 & 10 \\
\hline Handweeded & - & 68 & 82 & 88 & 85 \\
\hline Untreated & - & 10 & 15 & 20 & 3 \\
\hline LSD $5 \%$ & & 20 & 15 & 12 & 15 \\
\hline
\end{tabular}

'Areas were seeded 9 May 1980 and 21 April 1981 at Wellborn and College Station, TX respectively. Preplant incorporated, preemergence and postemergence herbicides were applied on 5 May, 13 May, and II June 1980 and 21 April and 11 May 1981 , respectively. Handweeded as needed.

6 since most were no different from the untreated areas. Areas receiving siduron at 2.2 and $4.5 \mathrm{~kg} / \mathrm{ha}$ had the least kleingrass, but were usually no different from other treatments. At College Station, handweeding was most successful in establishing kleingrass cover; other treatments were unsuccessful (Table 6).

In 1981, handweeded areas were also the most successful for kleingrass establishment at both locations with $85 \%$ or more ground cover (Table 6). Areas receiving application of glyphosate by the ropewick appicator on 11 or 20 May were successful in kleingrass establishment ( $37 \%$ or more ground cover) at Wellborn.
Mowing once (28 May) or twice (28 May and 14 July) 1981 also increased kleingrass cover. At the College Station site, the siduron treatment at 2.2 and $4.5 \mathrm{~kg} / \mathrm{ha}$ had 27 and $37 \%$ ground cover of kleingrass, respectively, compared to $3 \%$ for the untreated areas (Table 6).

In 1980, below-normal rainfall was received (drought conditions) during the growing season (data not shown). Excellent stands of kleingrass occurred where weeds were controlled (handweeded) to conserve soil moisture. In 1981, even though adequate rainfall was received, only treatments that successfully controlled weeds allowed sufficient kleingrass populations to survive (Tables 5 and 6).

Dry weights of kleingrass and weeds produced at College Station on areas treated in 1981 are shown in Table 7. The handweeded plots produced the most kleingrass $(4,458 \mathrm{~kg} /$ ha over dry

\section{Table 7. Effect of herbicides, mowing, and handweeding on dry weight production of kleingrass and weeds 7 months after seeding kleingrass on 21 April 1981 at College Station, TX.1}

\begin{tabular}{|c|c|c|c|c|c|}
\hline \multirow[b]{2}{*}{ Herbicide } & \multirow{2}{*}{$\begin{array}{c}\text { Type of } \\
\text { application }\end{array}$} & \multirow[b]{2}{*}{ Rate } & \multirow[b]{2}{*}{ Kleingrass $^{2}$} & \multicolumn{2}{|c|}{ Weeds $^{2}$} \\
\hline & & & & Grasses & Broadleaf \\
\hline & & & $-(\mathrm{kg} / \mathrm{ha})$ & & - \\
\hline Siduron & pre & 2.2 & 724 & 676 & 939 \\
\hline Siduron & pre & 4.5 & 1352 & 371 & 879 \\
\hline Asulam & poe & 2.2 & 42 & 1844 & 1149 \\
\hline 2,4-D & poe & 1.1 & 0 & 1328 & 0 \\
\hline Glyphosate & poe & 1.1 & 66 & 1328 & 0 \\
\hline Dalapon & poe & 4.5 & 222 & 646 & 844 \\
\hline Mowed twice ${ }^{3}$ & - & - & 132 & 1083 & 0 \\
\hline Mowed once ${ }^{3}$ & - & - & 377 & 335 & 0 \\
\hline Handweeded & - & - & 4458 & 60 & 0 \\
\hline Untreated & - & - & 0 & 1765 & 24 \\
\hline LSD 5\% & & & 848 & 712 & 706 \\
\hline
\end{tabular}

'Preemergence and postemergence herbicides applied on 24 April and 1I May 1981 respectively. Hand weeded as needed.

${ }^{2}$ Kleingrass and weeds were harvested 17 November 1981.

Mowed once on 14 July, and mowed twice on 28 May and 14 July 1981.

weight), 7 months after treatment. Application of siduron at 4.5 $\mathrm{kg} /$ ha produced $1,352 \mathrm{~kg} /$ ha of kleingrass. Broadleaf weeds were most abundant in the asulam, dalapon, and siduron treated areas $(844 \mathrm{~kg} / \mathrm{ha}$ or more). Most treatments, including glyphosate and dalapon, allowed abundant weedy grass production. Predominant grasses were broadleaf signalgrass and southern crabgrass. Dry weight production of kleingrass and weeds were not taken at Wellborn because of livestock use prior to harvest.

\section{Weed Control-Wellborn}

Most of the herbicides were not effective in controlling yellow nutsedge in 1980 and 19811 month after treatment (data not shown). Butylate + propazine at $2.2+2.2 \mathrm{~kg} /$ ha significantly reduced yellow nutsed ge in $1981\left(42\right.$ plants $/ \mathrm{m}^{2}$ for the treated plots versus 176 for the untreated plots).

Woolly croton was controlled by EPTC + dichlormid, EPTC, vernolate, pyrazon, and (butylate + propazine in 1980 and 1981, all at a total of $4.5 \mathrm{~kg} / \mathrm{ha}$ (data not shown). In 1980 and 1981 woolly croton numbers were also reduced by propazine at 1.1 and 2.2 $\mathrm{kg} / \mathrm{ha}$, pyrazon at $2.2 \mathrm{~kg} / \mathrm{ha}$, and butylate + propazine at $1.1+1.1$ $\mathrm{kg} / \mathrm{ha}$ when compared to the untreated area. Aside from handweeded treatment, woolly croton was controlled by 2,4-D at 1.1 $\mathrm{kg} / \mathrm{ha}$ both years, by bromoxynil at $1.1 \mathrm{~kg} / \mathrm{ha}$ in 1980 , and by mowing on 28 May 1981 .

Six months after application, none of the treatments effectively suppressed yellow nutsedge (data not shown). Propazine, pyrazon, butylate + propazine, asulam, 2,4-D, and ropewick applications of glyphosate controlled woolly croton. Mowing also significantly $(P>0.05)$ reduced woolly croton. 
Weed Control-College Station

One month after treatment, handweeding was the only treatment that controlled signalgrass in 1980 compared with the untreated areas (data not shown). In 1981, siduron at 2.2 and $4.5 \mathrm{~kg} / \mathrm{ha}$, butylate + propazine at $1.1+1.1$ and $2.2+2.2 \mathrm{~kg} / \mathrm{ha}$, asulam at 2.2 $\mathrm{kg} / \mathrm{ha}$, dalapon at $4.5 \mathrm{~kg} / \mathrm{ha}$, glyphosate at $1.1 \mathrm{~kg} / \mathrm{ha}$, and mowing effectively controlled signalgrass.

Six months after plot establishment in 1980 , only handweeding and mowing controlled signalgrass. Southern crabgrass was suppressed in plots treated with 2.2 or $4.5 \mathrm{~kg} / \mathrm{ha}$ of siduron and 4.5 $\mathrm{kg} / \mathrm{ha}$ of pyrazon. In 1981, all herbicides were ineffective in controlling signalgrass.

\section{Conclusions}

\section{Greenhouse Experiments}

Butylate was the only preemergence herbicide that did not significantly injure kleingrass or buffelgrass at rates of $2.2 \mathrm{~kg} / \mathrm{ha}$ or less. Kleingrass tolerated applications of pyrazon at 0.6 or $1.1 \mathrm{~kg} / \mathrm{ha}$ but buffelgrass was injured. Kleingrass tolerated profluralin at $\mathbf{0 . 6}$ $\mathrm{kg} / \mathrm{ha}$. All other herbicides applied preemergence caused extensive injury to both grasses. Bromoxynil applied postemergence was not phytotoxic to kleingrass at 0.6 or $1.1 \mathrm{~kg} / \mathrm{ha}$ and may have promise for broadleaf weed control in newly seeded stands. Bromoxynil, however, was injurious to buffelgrass. Kleingrass and buffelgrass were tolerant to postemergence treatments of barban and siduron up to and including 2.2 and $4.5 \mathrm{~kg} / \mathrm{ha}$, respectively. Kleingrass also tolerated postemergence sprays of pyrazon and asulam at 1.1 $\mathrm{kg} / \mathrm{ha}$.

\section{Field Experiments}

At Wellborn, kleingrass tolerated most thiocarbamate herbicides and propazine at $1.1 \mathrm{~kg} / \mathrm{ha}$ or propazine + butylate, but pyrazon and siduron sometimes reduced seedling populations of kleingrass. Most herbicides did not control yellow nutsedge, but several, including 2,4-D, controlled woolly croton. After 6 months in 1980, highest kleingrass cover occurred in the 2,4-D and handweeding treatments. In 1981, kleingrass establishment was best after treatment with glyphosate by ropewick application, mowing, or handweeding. At College Station, most promising kleingrass establishment was obtained in handweeded plots or areas treated with siduron.

These experiments demonstrate the difficulty of establishing forage grasses from seed because of dry weather and severe weed competition. Kleingrass seedlngs have a high drought tolerance and tenacity if weed control is adequate to allow growth and development, as demonstrated by handweeding. Several chemical and mowing treatments were reported that showed promise for effective weed control and successful kleingrass establishment.

\section{Literature Cited}

Bouse, L.F., and R.W. Bovey, 1967. A laboratory sprayer for potted plants. Weeds 15:89-91.

Bovey, R.W., J.R. Baur, and E.C. Bashaw. 1979. Tolerance of kleingrass to herbicides. J. Range Manage. 32:337-339.

Bovey, R.W., J.R. Baur, M.G. Merkle, and E.C. Bashaw. 1981. Response of kleingrass and buffelgrass to herbicides. Agron. J. 72:53-55.

Bovey, R.W., H. Hein, Jr., and R.E. Meyer. 1984. Effect of herbicides on the production of common buffelgrass (Cenchrus ciliaris). Weed Sci. 32:8-12.

Holt, E.C., and E.C. Bashaw. 1976. Developing improved grasses and legumes. Chap. 1, p. 7-9, In: E.C. Holt and R.D. Lewis (ed.) Grass and Legumes in Texas. Development, Production, and Utilization. Texas Agr. Exp. Sta. Res. Monogr. 6.

Steel, R.G.D., and J.H. Torric. 1980. Principles and procedures of statistics. McGraw-Hill Book Co. Inc., N.Y.

\section{Range Research: Basic Problems and Techniques}

\section{editors: C. Wayne Cook and James Stubbendieck}

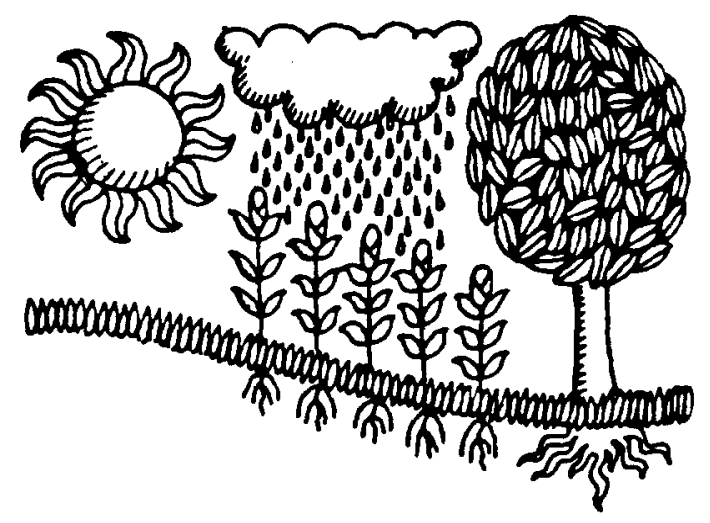

RANGE RESEARCH: BASIC PROBLEMS AND TECHNIQUES, a major revision of an earlier publication of the National Academy of Science, presents steps in research planning, evaluation of results, and methods and procedures in range research, including sampling techniques and experimental design. Chapter titles include: The Range Research Problem, Assessment of Habitat Factors, Methods of Studying Vegetation, Studies of Root Habits and Development, Methods of Measuring Herbage and Browse Utilization, Livestock Selection and Management in Range Research, Methods for Studying Rangeland Hydrology, Economic Research in Range Management, Sampling Methods with Special Reference to Range Management, Experimental Design, and Problems Involved in the Application of Research Techniques in Range Management. The book is designed to serve as a reference guide for range research methodology and as a textbook for advanced students who anticipate careers in this increasingly important field.

1986. 336 pages ISBN 09603692-3-6. \$28/hard.

Society for Range Management 2760 West Fifth Avenue, Denver, CO 80204 